\title{
Molecular Characterization of Phomopsis Blight and Fruit Rot Resistant and Susceptible Cultivars of Eggplant
}

\author{
M.M. Islam*, K.M. Alam, R. Momtaz, M. Arifunnahar, M.M. Karim \\ Plant Pathology Division, Bangladesh Agricultural Research Institute, Gazipur, Bangladesh
}

*Corresponding Author: M.M. Islam, Plant Pathology Division, Bangladesh Agricultural Research Institute, Gazipur, Bangladesh

\begin{abstract}
Eggplant (Solanum melongena L.) is one of the most important vegetable crops in respect of total acreage and production in Bangladesh with an average yield of ten tons per hectare, which is low as compared to other eggplant producing countries. It is widely and round the year cultivated popular vegetable in Bangladesh. Lot of variability of this crop exists in Bangladesh and as a bright scope to develop a new variety from this variability. The crop is prone to 12 different diseases. Among them, phomopsis blight caused by Phomopsis vexans is a devastating one. Keeping this view in mind, the present study was undertaken to characterize the six resistant and susceptible cultivars of eggplant viz. ISD-OO6, Laffa S, Jashore L, Ishurdi L, Dohazari and Katabegun WS at molecular level through Polymerase Chain Reaction (PCR). Out of six cultivars of eggplant, the highest genomic DNA concentration was found $50 \mathrm{ng} / \mathrm{ml}$ in cultivars of Ishurdi local (WS) and Jashore (L) and the lowest genomic DNA concentration $30 \mathrm{ng} / \mathrm{ml}$ was found in cultivar Dohazari. DNA and RNA fingerprinting by Variable Number Tandem Repeat (VNTR), Amplified Fragment Length Polymorphism (AFLP) and Real Time (RT) - PCR prompted the grouping of six resistant and susceptible cultivars into two groups.
\end{abstract}

Keywords: Molecular characterization, Phomopsis blight and fruit rot, Eggplant.

\section{INTRODUCTION}

Solanum melongena L. $(2 \mathrm{n}=24)$ is also known as eggplant, aubergine, brinjal and guinea squash. The total acreage of eggplant is 51,165 hectares with total annual production of 5,16,007 tones (Anon. 2019). It is the only economic host of Phomopsis vexans and the disease is variously known as tip over, stem blight, canker, leaf blight or spot and fruit rot; damping off also can take place. Leaf spots (up to $3 \mathrm{~cm}$ diam.) are conspicuous, irregular in outline and may coalesce; lower leaves may be affected first. In stem lesions, the cortex dries and cracks, plants become stunted and girdling cankers cause death of the plant. Fruit spots are pale sunken, conspicuous and may affect the whole fruit; fruit may drop or remain attached, becoming mummified after a soft decay. Pycnidia are abundant. Phomopsis vexans has both $\alpha$ and $\beta$ conidia, pycnidia with short or no pycnidial beaks. It is the sole causal agent of Phomopsis fruit rot of eggplant. Eggplant suffers from 12 diseases of which fruit rot caused by Phomopsis vexans (Sacc. and Syd.) Harter is a devastating one. This pathogen remains viable for about 14 months in soil debris and in the seed from infected fruits (Kalda et al. 1977). This organism is both externally and internally seed borne (Singh, 1992). The disease was first reported from Gujrat in 1914 and since then from many parts of India. Occurrence of the disease in Bangladesh has been reported by Fakir (1983) and Ahmad (1987). Crop losses range from 15-20 \% in general but $30-50 \%$ in severe case (Das, 1998). There is no data in the world on the molecular characterization of Phomopsis fruit rot resistant and susceptible cultivars of eggplant. The development of molecular techniques was allowed the cataloguing of many genes involved in defense. In recent years, both mini-satellite and micro-satellite probes have been applied for DNA fingerprinting of numerous animal, plant and fungal species. High levels of polymorphism between related genotypes were often observed and the technique found its way to diverse areas of genome analysis, including paternity testing, genotype identification and population genetics.

Milki et al. (2003) studied the genetic diversity among 26 cucumber accessions collected from five African countries (1 from Algeria, 21 from Egypt, 2 from Ethiopia, 1 from Kenya and 1 from Libya) 
for assessing variation at 71 polymorphic RAPD loci. Genetic distances (GD) and simple matching coefficients were estimated among the African accessions. The genetic distances among African accessions ranged between 0.41 and 0.97, and GD in the reference array ranged between 0.36 and 0.88. Multivariate analysis identified three distinct groupings. Group 1 contained 21 accessions (Egypt, Ethiopia and Libya), Group 2 consisted of 2 accessions (Kenya, Algeria), and Group 3 accessions (Egypt). While, GD among accessions in Group 1 ranged between 0.52 and 0.90, and distances among Group 2 accessions varied between 0.93 and 0.97 . The GD between the accessions (Group 1) possessed unique genetic variation, which indicated that these germplasm had potential for broadening the genetic base of commercial cucumber.Isshiki et al. (1998) conducted RFLP analysis of a polymerase chain reaction (PCR) amplified $3.2 \mathrm{~kb}$ region of ctDNA bounded by the conserved sequences in rbcL and ORP 106 was performed in eggplant and its related Solanum species. The results revealed that the restriction pattern divided the examined nine species into the following five clusters :(i) S. melongena and S. incanum (ii) S. virginianum (iii) S. torvum (iv) S. aethiopicum, $S$. violaceum and (v) S. mammosum. Karihallo and Gottlieb (1995) surveyed 29 isozyme loci to know the genetic relationship among 29 accessions of S. melongena, 33 accessions of weedy forms (referred to as insanum) and 2 accessions of wild forms (referred to as incanum). The results demonstrated that although the taxa included large morphological diversity but they had a very close genetic relationship. Isshiki et al. (1994) studied on inheritance and linkage relationship of isoenzymes of aspartate aminotransferase (AAT), alcohol dehydrogenase (ADH), phosphogluconate dehydrogenase (PGD), phosphoglucomutase and its wild relative S. indicum. Evidence of Mendelian inheritance was obtained for loci: Aat-1, Adh-1, Adh-2. Pgd-1, Pgm-1, Pgm-2 and Skdh-1. Tests of 22 pairs of loci for independent assortment suggested 3 linked pairs: Aat-2 with Pgd-2, Adh-2 with Pgm-1 and Pgd-2 with Pgm-2. PCR amplification of genomic DNA with RAPD/VNTR/AFLP primers produces numerous fragments that can be exceedingly variable among individuals and have proven useful for parentage analysis (Hadrys et al. 1993 and Scott and Williams 1993). RAPD/VNTR/AFLP has several other advantages over DNA fingerprinting protocols. The technique is fast and technically easy. Most importantly, no previous nucleotide sequence information is needed for the construction of primers. Many markers can readily be identified for a variety of taxonomic levels and in comparison with DNA sequencing, the effort and cost are modest so that many individuals can be assayed. Epidemiological and survey studies often involve screening large numbers of isolates (Bentley et al. 1995) and so RAPD/VNTR/AFLP or AP-PCR based methods are most suitable with respect to speed of processing, although the selection of suitable primers and applications condition may involve considerable initial work. Realizing the importance of this technology, a research program has been conducted on molecular variability of phomopsis fruit rot resistant and susceptible cultivars of eggplant in Bangladesh.

\section{Materials AND Methods}

The seeds of six eggplant cultivars viz. ISD-OO6, Laffa S, Jashore L, Ishurdi L, Dohazari and Katabegun WS were collected from IPM laboratory, Department of Plant Pathology, Bangladesh Agricultural University (BAU), Mymensingh and the experiment was conducted in Plant Pathology Division, BARI, Gazipur. Seedlings were raised in plastic trays in the net house with proper care and management. Fresh green leaves of 6 eggplant cultivars viz. ISD-OO6, Laffa S, Jashore L, Ishurdi L, Dohazari and IPM 31 were collected from one-month-old seedlings for DNA extraction. Collected leave portions were cut into small pieces (about $0.5 \mathrm{~cm}$ ) and leave pieces folded into an Al-foil paper, placed in a porcelain mortar and quickly placed in freezer at $-20{ }^{\circ} \mathrm{C}$ until ground for DNA extraction i.e. for at least one hour. Totals genomic DNA isolation was done by using the large-scale CTAB (Hexadecyl Trimethyl -Ammonium Bromide) method. This method was adopted from Dellaporta $e t$ al. (1993).Frozen leaf samples were ground using mortar and pestle. An approximate amount of 200 $\mathrm{mg}$ of powderized tissue samples were placed into $1.5 \mathrm{ml}$ of sterile micro-centrifuge (about $1 / 3$ full) and replaced into freezer at $-20^{\circ} \mathrm{C}$ until this had been completed with all samples. All tubes were taken from the freezer and homogenized with $800 \mu \mathrm{l}$ of extraction buffer $(250 \mathrm{M} \mathrm{NaCl}, 100 \mathrm{mM}$ Tris-HCl, $100 \mathrm{mM}$ EDTA, all Sigma) by stirring on Vortex mixer for lyses of the cells. The mixture was incubated in water bath at $65^{\circ} \mathrm{C}$ for 20 minutes mildly shaking the water bath by inversion every few 
minutes. After incubation, the tubes were centrifuged (Hawk 15/05) at $13000 \mathrm{rpm}$ for 5 minutes and $750 \mu \mathrm{l}$ supernatant were collected from the upper layers and transferred in a new tube and then added with $800 \mu \mathrm{l}$ of $5 \mathrm{MNaCl}$ and $47 \mu \mathrm{l}$ water which was mixed thoroughly followed by addition of $112 \mu \mathrm{l}$ of $10 \% \mathrm{CTAB}$. Then the supernatant was mixed by inversion and heated to $65^{\circ} \mathrm{C}$ in a water bath for 20 minutes. Five hundred micro-liter of chloroform was added for two times to the new centrifuge tube and mixed thoroughly on vortex mixer. Chloroform precipitates the protein and long centrifugation separates long chain polysaccharides from the DNA. The upper aqueous phase (the DNA solution) was collected into clean tubes very carefully with the help of a pipette without disturbing the amphibathic natured protein interface and discarded the protein interface with the organic phase layer beneath the interface. One mili-liter of $1 \%$ CTAB was added with extract and mixed by inversion for 2 minutes and followed by centrifugation at $13000 \mathrm{rpm}$ for 5 minutes. Precipitation of DNA was done following the procedure of Anon. (2001). One volume of pure isopropanol was added into the DNA solution, kept on ice for 10 minutes and allowed the DNA molecules to aggregate. The DNA was precipitated down by centrifuge at $13000 \mathrm{XG}$ at $4^{0} \mathrm{C}$ for 5 minutes to the bottom of the centrifuge tube as pellet. Then the supernatant was discarded with the help of a wide bore pipette and the centrifuge tube with the DNA pellet preserved. Two hundred micro-liter of $70 \%$ ethanol was added into the centrifuge tube, stirred on Vortex mixer for washing the DNA pellet and centrifuged at $13000 \mathrm{XG}$ at $4^{0} \mathrm{C}$ for two minutes. Ethanol was discarded with the help of a micropipette and the DNA pellet preserved. The centrifuge tube containing DNA pellet was dried in a vacuum desiccators for two minutes and re-suspended the DNA pellet in required volume of tris-EDTA (TE) buffer (10 mM Tris, pH-8.0, 1 M EDTA, all Sigma). Depending on the size of DNA pellet, the solution was preserved at $-20^{\circ} \mathrm{C}$ for further experiments. The DNA was assessed following the procedure of Anon. (2001). Two micro-liter of 6X gel-loading dye was mixed with $8 \mu \mathrm{l}$ of each of the genomic DNA solution in separate centrifuge tubes for each of the isolates.

RNA was extracted from two grams of fresh leaves (from one month old seedlings grown in the growth chamber, $24{ }^{0} \mathrm{C}$ ) were ground in buffer and extraction procedure was followed as outlined in Qiazen Rneasy Miniprep Plant Extraction Kit (Nassuth et al 2000).RT-PCR reaction was performed in a $25 \mu \mathrm{l}$ volume consisting of $2.5 \mu \mathrm{l}$ of $10 \mathrm{X}$ PC Buffer (Fermantas), $5 \mu \mathrm{KCl}(0.25 \mathrm{M}), 2.5 \mu 1$ Sucrose-cresol red (10 X, $20 \%), 0.7 \mu 1 \mathrm{MgCl}_{2}(50 \mathrm{mM}), 0.5 \mu \mathrm{dNTPs}(10 \mathrm{mM} \mathrm{Mg}$ balanced dNTPs), $1.26 \mu \mathrm{l}$ DTT $(0.2 \mathrm{M}), 0.1 \mu \mathrm{l}$ AMVR Tase $(1 \mathrm{U} / \mu \mathrm{L}), 0.5 \mu \mathrm{l}$ each of two primers $(25 \mu \mathrm{M}), 0.4$ Taq Polymerase $(5 \mathrm{U} / \mu \mathrm{L}), 2.5 \mu \mathrm{l}$ RNA and $8.5 \mu \mathrm{l}$ water. For control reaction, RNA was substituted by sterile distilled water to ensure that there was no contamination. PCR amplification was carried out in a thermo cycler (PTC- $100^{\mathrm{TM}}$ Programmable Thermal Controller. MJ Research, INC.) programmed for an initial denaturation for $3 \mathrm{~min}$ at $94^{\circ} \mathrm{C}, 35$ cycles of $45 \mathrm{~S}$ at $92^{\circ} \mathrm{C}, 45 \mathrm{~S}$ at $45^{\circ} \mathrm{C}$ and 2 min at $72^{\circ} \mathrm{C}$ followed by final extension step for $10 \mathrm{~min}$ at $72^{\circ} \mathrm{C}$. After extraction of DNA and RNA, characterize the six resistant and susceptible eggplant cultivars viz. ISD-OO6, Laffa S, Jashore L, Ishurdi L, Dohazari and Katabegun WS were done at molecular level through Variable Number Tandem Repeat (VNTR), Amplified Fragment Length Polymorphism (AFLP) and Real Time (RT) - PCR. Rice DNA sample was used as positive control in conventional PCR and tomato DNA was used as positive control in RT-PCR. Primer MR-20 (GAG GGT GGC GGT TCT) and AFLP-5 (GACTGCGTACATGCAGGAC) were used in the VNTR-PCR and AFLP-PCR, respectively. Two primers viz. P-loop (GGIGGIRTIGGIAAIACIAC) and GLPLAL-1(IAGIGYIAGIGGIAGICC) were used in the RT-PCR. After completion of both the PCR, the electrophoresis of the gel and its staining and the photographing of the DNA and RNA bands were done accordingly.

\section{Results}

Out of six cultivar of eggplant, the highest genomic DNA concentration was found $50 \mathrm{ng} / \mu \mathrm{l}$ in cultivars of Ishurdi local (WS) and Jashore (L), and $40 \mathrm{ng} / \mu \mathrm{l}$ was found in Katabegun WS, ISD-006 and Laffa (S). The lowest genomic DNA concentration 30ng/ $\mu$ l was found in cultivar Dohazari (Tables 1 and 2). DNA samples of six cultivars with a negative control (the reaction mixture without DNA) and one rice sample were used in the Polymerase Chain Reaction (PCR) analysis where 6 eggplant samples and one rice sample showed the expected banding patterns excluding negative 
control. The positive control (eggplant DNA and rice DNA) showed strong PCR product amplification, whereas the negative control (the reaction mixture without DNA) did not reveal any amplification. The primer MR-20 was used for VNTR-PCR to detect the DNA fingerprint of all eggplant samples including negative control and rice sample. The DNA fingerprinting patterns for the cultivars of Dohazari, Katabegun WS, Ishurdi local (WS) and Laffa (S) were more or less same (Fig. 1a).

Table1. Molecular behavior of eggplant cultivars in VNTR-PCR

\begin{tabular}{|l|l|l|l|l|l|l|}
\hline $\begin{array}{c}\text { Sample } \\
\text { No }\end{array}$ & \multicolumn{1}{|c|}{ Variety } & \multicolumn{1}{|c|}{$\begin{array}{c}\text { Amount of } \\
\text { TE added }(\boldsymbol{\mu l})\end{array}$} & $\begin{array}{c}\text { DNA concentration } \\
(\mathbf{n g} / \boldsymbol{\mu} \mathbf{l})\end{array}$ & Primer & \multicolumn{1}{|c|}{ PCR } & Grouping \\
\hline 1 & Dohazari & 50 & 30 & MR-20 & Positive & 1 \\
\hline 2 & Katabegun WS & 50 & 40 & MR-20 & Positive & 1 \\
\hline 3 & ISD-006 & 50 & 40 & MR-20 & Positive & 2 \\
\hline 4 & Ishurdi local (WS) & 50 & 50 & MR-20 & Positive & 1 \\
\hline 5 & Laffa (S) & 50 & 40 & MR-20 & Positive & 1 \\
\hline 6 & Jessore (L) & 50 & 50 & MR-20 & Positive & 2 \\
\hline 7 & - Control & - & - & MR-20 & Negative & - \\
\hline 8 & Rice & - & - & MR-20 & Positive & - \\
\hline
\end{tabular}

Primer: MR-20 (5' GAGGGTGGCGGTTCT 3').

In the cultivars Jashore (L), one prominent band is missing in upper portion of the pattern. But this band is less visible in the cultivar Katabegun WS and ISD-006 compared to other cultivars. In case of AFLP-PCR, primer AFLP-5 was used to detect the DNA fingerprinting. Here, two bands were missing in the middle portion of the cultivars Laffa (S) and Jashore (L) from the other 4 cultivars besides two more bands were visible in the middle portion of the same two cultivars (Fig 1b).

To the contrast of RT-PCR, amplification of RNA/DNA of eggplant with degenerate primers resulted in mostly one to a few bands with $1.5 \%$ agarose gel. With one pair of primers (P-loop/LDD-As), bands of 200-300bp in 4 to 6 cultivars while with other pair of primers (P-loop/GLPLAL-1) band of $600-700 \mathrm{bp}$ was detected only in one cultivar. It is remarkable that the banding pattern of 6 cultivars of eggplant is different from one to one considering position, coarseness and visibility. In the picture, 4 , $3,3,3,1$ and 2 band are distinct in the samples 1, 2, 3, 4, 5 and 6, respectively. No band is distinct in the sample 4 i.e cultivar Ishurdi local (Fig. 2).

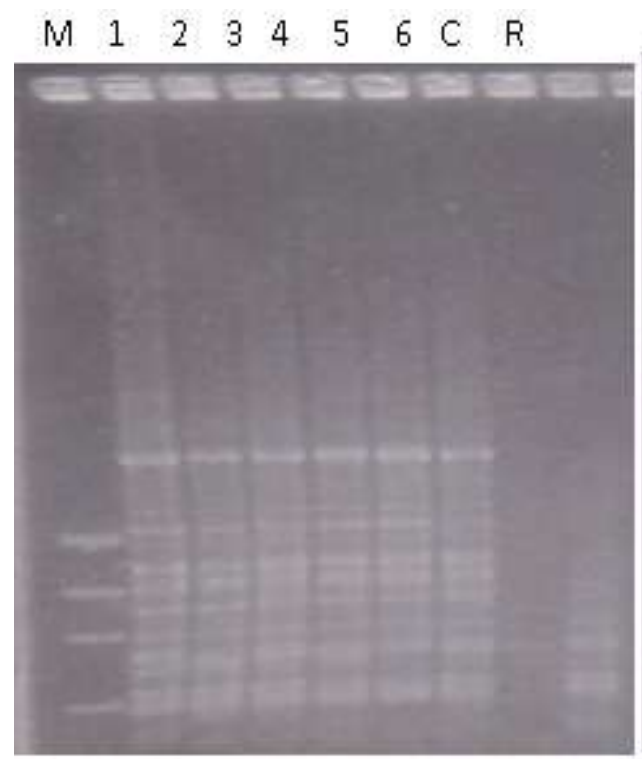

(a)

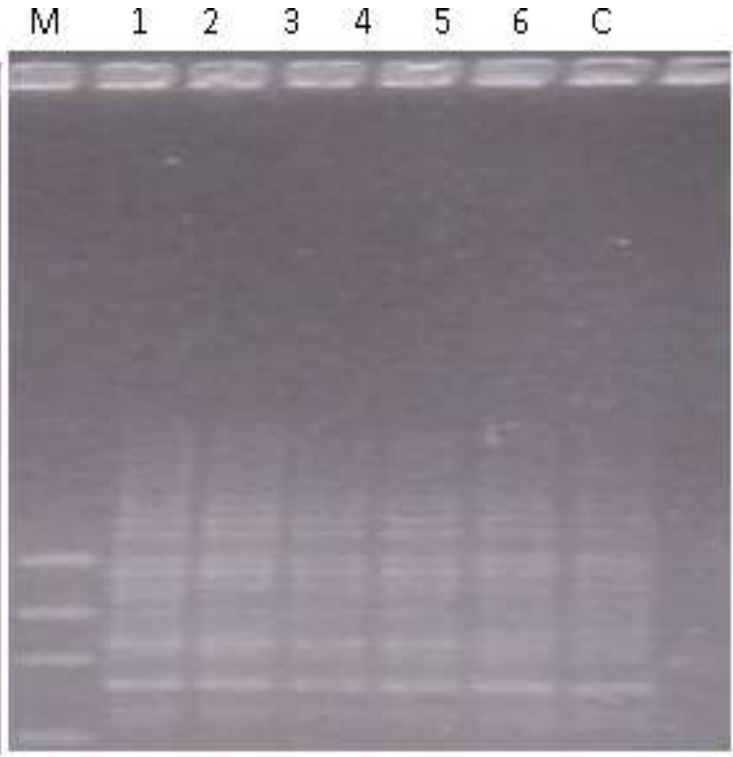

(b)

Fig1. PCR amplification of (a) variable number of tandem repeats (VNTR) and (b) amplified fragment length polymorphism (AFLP) from 6 eggplants using MR 20. [Lanes: M. Phi x 174 DNA/Hae III molecular weight markers. 1-Dohazari, 2- Katabegun WS, 3-ISD-006, 4-Ishurdi local (WS), 5-Laffa (S), 6-Jashore (L), C-No DNA template (negative control). R= Rice 

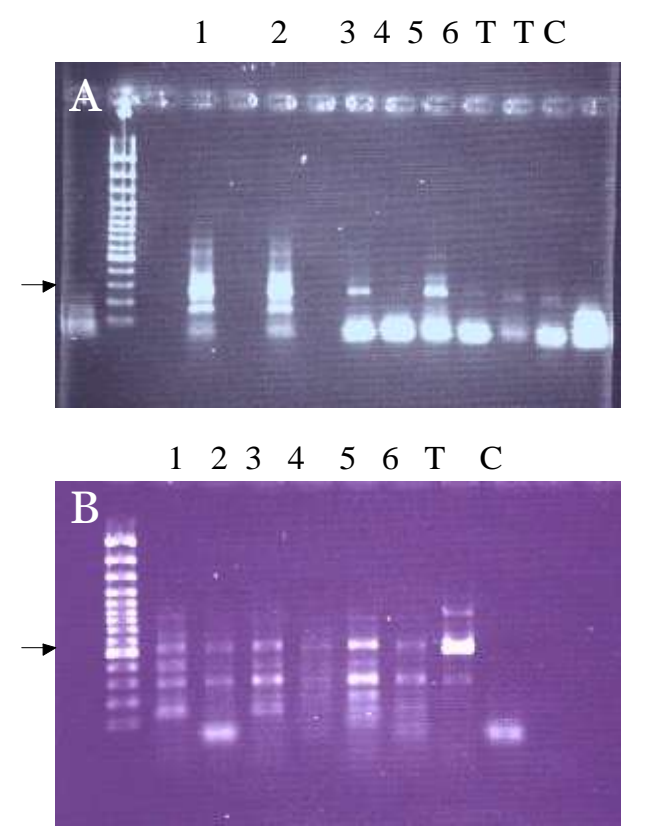

$\square$ A: P -loop/LDD - AS

$\square$ B: P - loop/GLPLAL -1

\author{
Eggplant Cultivars \\ 1 : Dohazari \\ 2 : Katabegun ws \\ 3 :Isd - oo6 \\ 4 : Isd - L \\ 5:Laffa $S$ \\ 6:Jashore L \\ Tomato (T) \\ C: - ve control
}

Fig2. RNA analysis of six eggplant cultivars with tomato and -ve control using degenerate primer through RTPCR amplification

Table2. Molecular behavior of eggplant cultivars in AFLP-PCR

\begin{tabular}{|l|l|l|l|l|l|l|}
\hline $\begin{array}{l}\text { Sample } \\
\text { No }\end{array}$ & Variety & $\begin{array}{l}\text { Amount of } \\
\text { TE added }(\boldsymbol{\mu l})\end{array}$ & $\begin{array}{l}\text { DNA concentration } \\
(\mathbf{n g} / \boldsymbol{\mu l})\end{array}$ & Primer & PCR & Grouping \\
\hline 1 & Dohazari & 50 & 30 & AFLP-5 & Positive & 1 \\
\hline 2 & Katabegun (WS) & 50 & 40 & AFLP-5 & Positive & 1 \\
\hline 3 & ISD-006 & 50 & 40 & AFLP-5 & Positive & 1 \\
\hline 4 & Ishurdi local (WS) & 50 & 50 & AFLP-5 & Positive & 1 \\
\hline 5 & Laffa (S) & 50 & 40 & AFLP-5 & Positive & 2 \\
\hline 6 & Jessore (L) & 50 & 50 & AFLP-5 & Positive & 2 \\
\hline 7 & - Control & - & - & AFLP-5 & Negative & - \\
\hline
\end{tabular}

\section{DISCUSSION}

Phomopsis fruit rot resistant and susceptible cultivars of eggplant were characterized by VNTR-PCR, AFLP-PCR and RT-PCR by employing DNA and RNA fingerprinting. These comprehensive analyses enabled us to select molecular nature of Phomopsis fruit rot resistant and susceptible cultivars of eggplant. This study is the first to describe the molecular characteristics of eggplants against Phomopsis fruit rot. Six eggplants were selected for molecular characterization, all belonging to one species, S. melongena. According to DNA fingerprinting, 6 eggplants were categorized into 2 groups both in VNTR-PCR and AFLP-PCR. Cultivars 1, 2, 4 and 5 were grouped into one and 3 and 6 into group two in VNTR-PCR. But in the AFLP-PCR, cultivars 1, 2, 3, and 4 in group one and 5 and 6 in group two. Again in the RT-PCR, 6 cultivars are different in their banding patterns. Isshiki et al. (1998) reported that RFLP analysis of a polymerase chain reaction (PCR) amplified $3.2 \mathrm{~kb}$ region of ctDNA bounded by the conserved sequence in rbcL and ORP was performed in eggplant and its related Solanum species. His results revealed that the restriction pattern divided the examined nine species into five clusters: (i) $S$. melongena and $S$. incanum, (ii) S. virginianum, (iii) $S$. torvum, (iv) $S$. aethiopicum, S. violaceum, and $S$. mammosum. So the present findings corroborate with the report of Isshiki et al. (1998) although they did not work with resistant and susceptible eggplants.

Primer MR-20 and AFLP-5 were not species specific. Alternatively, a more specific MR-20 and AFLP-5 primer could be developed. New primers can easily be incorporated into this PCR based assay, thereby providing a means for continually updating and improving the specific and sensitivity of the assay. Degenerate Primers are also used to direct the amplification of specific plant rice, barley, 
maize, sugar beet, wild apple etc (Hunger et al. 2003, Leister et al. 1996 and Pan et al. 2000a). So amplification of eggplants DNA through RT-PCR by using degenerate primer was also positive.

The variability in PCR results of 6 cultivars may be due to variations in genetically make-up in the samples. All eggplant cultivars produced distinct banding patterns whereas the negative control samples without any DNA did not produce any band. This indicated that the results were not a false positive by PCR contamination. In picture, many bands are generated as the primer anneals in 10ds of different places. Each uses the same primer and conditions but a DNA sample from different eggplants. The patterns of group- 1 and group- 2 of 6 cultivars are more or less similar indicating that they are in the same group. To distinguish interspecific and intraspecific variability of the eggplant, molecular markers allowed the detection of differences among different eggplant varieties. Moreover, molecular analysis was able to classify cultivatrs of eggplant into 2 different groups. Thus VNTR and AFLP analysis overcame the limitation of classifying cultivars based on morphological characteristics only.

Karihallo and Gottlieb (1995) surveyed 29 isozyme loci to know the genetic relationship among 29 accessions of S. melongena, 33 accessions of weedy forms (referred to as insanum) and 2 accessions of wild forms (referred to as incanum). The results demonstrated that although the taxa included large morphological diversity but they had a very close genetic relationship. Mian et al (2002) reported that comparison of groupings by the different methods mostly agree with each other and sometimes grouping may be in disagreement between two methods and in these cases data may be used to subdivide groups. In our study, grouping different cultivars of eggplant based on similarity of band patterns corresponded with grouping them based on disease reaction. Because of the congruence of both morphological and VNTR/AFLP groupings and the correspondence among cultivars, it was concluded that grouping assignment of the eggplants was appropriate. Even when, in our study, 6 eggplants were used, both morphological and molecular analysis allowed the separation of the different groups of the eggplant cultivars present in the core eggplant producing areas of Bangladesh. The results of the present study indicate the presence of variability and diversity among the genotypes which will be useful for development of disease resistant eggplant cultivars.

\section{CONCLUSiON}

Six cultivars of eggplant viz. ISD-OO6, Laffa S, Jashore L, Ishurdi L, Dohazari and Katabegun WS were characterized at molecular. The highest genomic DNA concentration was found $50 \mathrm{ng} / \mu \mathrm{l}$ in cultivars of Ishurdi local (WS) and Jashore (L) and the lowest genomic DNA concentration 30ng/ $\mu \mathrm{l}$ was found in cultivar Dohazari. DNA and RNA fingerprinting by VNTR, AFLP and RT - PCR prompted two grouped of six resistant and susceptible cultivars.

\section{ACKNOWLEDGEMENTS}

The authors thankfully acknowledge Bangladesh Agricultural Research Institute, Gazipur to provide financial support and logistic support. Special thanks to Dr. Firoza Khatun, Chief Scientific Officer and Head Plant Pathology Division, BARI for her fruitful discussions. Thanks go to Most. Shainur Akter (Scientific Assistant) for her sincere assistance in this research work.

\section{REFERENCES}

[1] Ahmad Q.1987. Sources of resistance in brinjal to Phomopsis fruit rot. Indian Phytopathol. 40(1): 89.

[2] Anonymous.2001. Molecular Cloning: a laboratory manual. (Eds. Sambrook, Joseph and David W. Russel, $3^{\text {rd }}$ edition. Vol. I, II and III). Cold Spring Harbor, New York.

[3] Anonymous. 2019. Statistical Yearbook of Bangladesh. Bangladesh Bureau of Statistics. Ministry of Planning, Government of the People's Republic of Bangladesh. Dhaka, Bangladesh. pp. 249-290.

[4] Bentley S, Pegg KG and Dale JL. 1995. Genetic variation among a worldwide collection of isolates of Fusarium oxysporum f. sp. cubens analyzed by RAPD-PCR fingerprinting. Mycol. Res. 99: 1378 - 1384.

[5] Das BH. 1998. Studies on Phomopsis fruit rot of brinjal. An M.S. thesis submitted to the Department of Plant Pathology. BAU, Mymensingh.pp.29-64.

[6] Delaporta SL, Woo J and Hicks JB. 1993. A plant DNA minipreparation version I. Plant Mol. Biol. Rep. $1: 19-21$. 
[7] Fakir GA. 1983. Root and stem rot of brinjal caused by Phomopsis vexans. Proceedings of 8th Bangladesh Sci. Con. Section 1 pp.67-68.

[8] Hadrys H, Schierwater B, Dellaporta SL, Desale SL. Desale R and Buss LW. 1993. Determination of paternity in dragonflies by random amplified polymorphic DNA fingerprinting. Molecular Ecology 2: 7987.

[9] Hunger S, Gaspero GD, Mohring H, Bellin D, Schafer PR, Werber M, Weisshaar B, Salamini F and Schneider K. 2003. Isolation and linkage analysis of expressed disease-resistance gene analogues of sugar beet (Beta vulgaris L.). Genome, NRC. Canada. 46(1): 70-82.

[10] Isshiki S, Okubo H and Fujieda K. (1994) Euphytica, 80: 145-150.

[11] Isshiki S, Uchiyama T, Tashiro Y and Miyazaki S. 1998. Euphytica, 102: 295-299.

[12] Kalda TS, Swarup V and Choudhury B. 1977. Resistance to Phomopsis blight in eggplant. Vegetable Sci. India. 4(2): 90-101.

[13] Karihallo JL and Gottlieb LD. (1995) Theor. Appl. Genet. 90: 578-583.

[14] Leister D, Ballvora A, Salamini F and Gebhardt C. 1996. A PCR-based approach for isolating pathogen resistance genes from potato with potential for wide application in plants. Nat. Genet. 14: 421-429.

[15] Mian SM, Stevens C and Mia MAT. 2002. Methods of DNA fingerprinting to difference strains of Pyricularia grisea from Bangladesh. Bangladesh J. Plant Pathol. 18(1\&2): 19-26.

[16] Milki A, Staub JE, Sun ZY and Ghorbel A. 2003. Genetic diversity in African cucumber (Cucumis sativus L.) provides potential for germplasm enhancement. Genet. Reso. Crop Evol., 50(5) : 461-468.

[17] Nassuth A, Pollari E, Helmeczy K, Stewart S and Kofavi S. 2000. Improved RNA extraction and one-tube RT-PCR assay for the simultaneous detection of control plant RNA plus several viruses in plant extracts. J. Virol. Methods 90:37-49.

[18] Pan QL, Wendel J and Fluhr R. 2000b. Divergent evolution of plant NBS-LRR resistance gene homologues in dicot and cereal genomes. J. Mol. Evol. 50:203-213.

[19] Pan S and Acharya S. 1995. Studies on the seed borne nature of Phomopsis vexans (Sacc. and Syd.). Harter Indian Agriculturist 39(3): 193-198.

[20] Scott MP and Williams SM. 1993. Comparative reproductive success of continually breeding burying beetle as assessed by PCR with randomly amplified polymorphic DNA. Proc. of the National Academy Sciences, USA. 90: $2242-2245$.

[21] Singh RS. 1992. Diseases of Vegetable crops, second edn. Oxford and IBH publishing company Pvt. Ltd. New Delhi, Bombay, Calcutta.pp. 119-121.

Citation: M.M. Islam, K.M. Alam, R. Momtaz, M. Arifunnahar, M.M. Karim, "Molecular Characterization of Phomopsis Blight and Fruit Rot Resistant and Susceptible Cultivars of Eggplant. International Journal of Research Studies in Biosciences. 2020; 8(7): 21-27. DOI: https://doi.org/10.20431/2349-0365.0807004.

Copyright: () 2020 Authors. This is an open-access article distributed under the terms of the Creative Commons Attribution License, which permits unrestricted use, distribution, and reproduction in any medium, provided the original author and source are credited. 